\title{
IdeAs
}

Idées d'Amériques

$6 \mid 2015$

Migrer dans les Amériques

\section{Rolling Out the Welcome Mat: State and City Immigrant Affairs Offices in the United States}

Els de Graauw

\section{OpenEdition}

1 Journals

Édition électronique

URL : https://journals.openedition.org/ideas/1293

DOI : $10.4000 /$ ideas. 1293

ISSN : 1950-5701

Éditeur

Institut des Amériques

Référence électronique

Els de Graauw, « Rolling Out the Welcome Mat: State and City Immigrant Affairs Offices in the United States », IdeAs [En ligne], 6 | 2015, mis en ligne le 17 décembre 2015, consulté le 19 octobre 2022. URL : http://journals.openedition.org/ideas/1293; DOI : https://doi.org/10.4000/ideas. 1293

Ce document a été généré automatiquement le 19 octobre 2022

\section{(c) (i) (9)}

Creative Commons - Attribution - Pas d'Utilisation Commerciale - Pas de Modification 4.0 International - CC BY-NC-ND 4.0

https://creativecommons.org/licenses/by-nc-nd/4.0/ 


\title{
Rolling Out the Welcome Mat: State and City Immigrant Affairs Offices in the United States
}

\author{
Els de Graauw
}

\section{Introduction}

1 Since 1965, the United States has admitted over 36 million legal immigrants, and millions more have entered the country clandestinely. Compared with the white Europeans who dominated the great wave of migration at the turn of the twentieth century, today's immigrants tend to be people of color from Asia, Latin America, the Caribbean, and Africa. While bifurcated in terms of skills and human capital, many of the newer immigrants lack formal educational credentials, have limited English skills, struggle with poverty, and are not U.S. citizens. They have yet to achieve social, economic, civic, and political parity with native-born Americans. Today's foreign-born population of 41 million also includes an estimated 11.3 million undocumented immigrants, who face the toughest integration barriers.

2 Although a classic country of immigration, the United States has no national program to integrate immigrants, and immigrants are expected to become part of society through their own hard work, the help of family and friends, and perhaps the assistance of community organizations, not through federal policies. In recent decades, public debate and federal government action have focused on border control, immigration enforcement, and the question of what to do with the large population of resident undocumented immigrants. Yet for immigrants to succeed and thrive, it is important for all levels of government to develop intentional strategies to help immigrants achieve the greater social inclusion, economic mobility, and civic and political voice that their contributions to American society warrant.

3 In the absence of a federal integration program, much of the government responsibility to advance immigrant integration has rested with cities and increasingly states. This 
was true historically, when urban political machines helped with the social, economic, and political integration of the large wave of European immigrants, though they often did so coercively and for self-interested political reasons. While political parties today are less willing to fulfil this role, state and local governments-and big city mayors in particular-have stepped in to fill the integration policy void. This article takes a look at state and city offices created in recent years to foster immigrant integration. It provides an overview of current immigrant affairs offices and where in the United States they can be found. It also discusses their goals, activities, and challenges as well as the lessons learned from the work they have done thus far.

\section{State and City Immigrant Affairs Offices}

\section{How Many Are There and Where Are They Located?}

4 There are currently four state offices serving immigrant and refugee populations: the Massachusetts Office for Refugees and Immigrants (created in 1985), the Illinois Office of New Americans (2005, but defunded in 2015), the New York State Office for New Americans (2012), and the Michigan Office for New Americans (2014). California and Pennsylvania have either introduced or passed legislation to create an office. All four existing offices were created by executive order, indicating the importance of the governor's support to launch a state immigrant affairs office. The New York office was subsequently codified through legislation, making the office more immune from gubernatorial transitions.

5 Additionally, twenty-eight cities have immigrant affairs offices under a variety of names, including the Office of New Bostonians in Boston, the Mayor's office of Immigrant Affairs in New York City and Atlanta, and the Office of International Communities in Houston. All city offices have been created under the auspices of the mayor. They can now be found in most big cities, including those with long and continuous migration histories (New York City, Boston, Chicago, and San Francisco), but also newer (Atlanta, Nashville) and former and reemerging immigrant destinations (Detroit and Philadelphia). The oldest office, created in 1986, is in New York City, which also happens to be the biggest and best resourced office with fifty full-time staff. Most other offices have been created only in the last ten years, are less institutionalized, have only one to two paid staff, and operate on limited resources.

Besides formal offices, many municipalities (at least thirty-five) have developed committees, commissions, and task forces dedicated to immigrant issues. These are less institutionalized, often with a narrow focus and finite set of tasks, but they could be a first step toward creating a formal office. Examples include the Immigrant Integration Task Force in Charlotte (NC) and the Immigrant Task Force in Tucson (AZ). Additionally, ninety-two cities and counties across the country are members of Welcoming America, a nonprofit organization headquartered in Atlanta that works with municipalities to build welcoming communities that foster immigrant integration. Finally, eighty-nine mayors and county commissioners are members of Cities United for Immigration Action, a large coalition of municipal governments that support building stronger, welcoming, and inclusive cities through immigration action. Together, city immigrant affairs offices and other local immigrant-focused initiatives 
demonstrate that the biggest push for immigrant integration in the United States is coming from local government.

7 Given the great variety of municipal integration initiatives, there is no easy way to classify them. That said, large cities with long migration histories and a well-developed infrastructure of immigrant advocacy organizations, such as New York City, Chicago, and San Francisco, have the most formalized and best resourced offices with the broadest range of programs focused on immigrants' socioeconomic, civic, and political integration. Cities that have experienced decades of native-born population loss, rapidly aging populations, and deep economic malaise, including rustbelt cities like Detroit, Philadelphia, and Buffalo, have started immigrant affairs offices more recently, often with a focus on attracting immigrants to help reverse population decline and revitalize local economies. And cities with recent increases in their immigrant populations, particularly southern cities like Atlanta, Houston, and Nashville that are characterized by anti-immigrant environments and state opposition to immigrant rights, have started immigrant affairs offices to help diffuse tensions and temper local hostilities between immigrants and native-born residents, including African Americans. In other words, local and state context plays an important role in explaining when, why, and for what purpose city immigrant affairs offices are created.

\section{What Do They Do?}

8 State and city immigrant affairs offices differ in when and why they were created, their structure, organization, degree of institutionalization, and the amount of resources they have to get things done. Yet we can identify commonalities in what they do and seek to accomplish. First, all immigrant affairs offices welcome immigrants and refugees and seek to change the public discourse on immigration, immigrants, and refugees. To this end, they convene a broad range of local stakeholders-law enforcement and other city officials, nonprofit service providers, immigrant advocacy organizations, religious institutions, and business organizations-to foster interactions between immigrants and native-born residents. They thereby strive to make immigrants and non-immigrants recognize that they have common aspirations and goals for the benefit of the entire community.

Second, state and city immigrant affairs offices make the case that immigrants are of current and future economic importance to states and cities (and the larger nation). They highlight the economic contributions of immigrants and refugees and have developed programs and initiatives to retain immigrant talent, support immigrant entrepreneurs, and increase immigrants' economic contributions. The Mayor's office of Immigrant Affairs in New York City, for example, works with the city's Economic Development Corporation and the Department of Small Business Services to make it easier for immigrant-owned businesses to start and grow by offering free business courses in foreign languages and by hosting a business plan competition to promote seed funding to immigrant entrepreneurs. Similarly, the Seattle Office of Immigrant and Refugee Affairs developed a "Ready to Work" program that combines English classes with computer literacy instruction and case management to help immigrants gain job readiness skills and take steps toward greater economic self-sufficiency.

Third, state and city immigrant affairs offices coordinate and streamline state and city efforts that can foster immigrant integration. Immigrants have needs and interests 
similar to those of other state and city residents, but language barriers and lack of citizenship or legal status create access and trust barriers that make it difficult for other state and city agencies to assist them. These agencies may not have the resources or expertise to serve immigrants. Alternatively, their varied efforts can be duplicative and inefficient. Much of the work of the Mayor's Office of New Bostonians, for example, is to help transform city agencies and departments in such a way that immigrants and refugees feel comfortable going to them directly for assistance. Similarly, a key role for the Mayor's Office of Immigrant Affairs in New York City is to bring an immigrant integration lens to the varied work that other city agencies and departments do so that taking immigrants' needs and interests into consideration becomes part and parcel of how the larger city bureaucracy works.

11 Fourth, state and city immigrant affairs offices encourage immigrant civic engagement, invest in immigrant leaders, and nurture new community organizations that serve immigrants. Such efforts can start small with limited resources by holding citizenship ceremonies, organizing diversity celebrations, and recruiting volunteers for city events. Resources permitting, they can include grander initiatives like that undertaken by the San Francisco Office of Civic Engagement and Immigrant Affairs. Since 2014, that office has funded the "DreamSF Fellowship" program, a thirty-week program that provides youth with deferred action ${ }^{1}$ status the opportunity to do paid work with community organizations to serve the city's immigrants while gaining valuable professional and leadership training. Similarly, the Mayor's Office of Immigrant Affairs in New York City has started a four-month "Immigrant Women Leaders Fellowship" to help immigrant women become effective social change leaders in the human services field and in the city's immigrant communities.

12 Finally, more institutionalized offices also develop and implement policies that promote immigrant integration. The immigrant affairs offices in San Francisco, Washington, D.C., and New York City, for example, have helped to enact and implement language access policies that require city agencies and departments to offer government information and public services in several foreign languages. The New York City office also supported municipal ID card legislation and today plays a key role in the implementation of the IDNYC program. This city-issued ID card is available to undocumented immigrants and other city residents, who can use it to open a bank account, access basic city services, and identify themselves to police and other city officials. The immigrant affairs offices in several other cities-including Boston, Nashville, San Francisco, and Seattle-have developed new initiatives to promote the local implementation of the Deferred Action for Childhood Arrivals program. Similarly, many state and city immigrant affairs offices have developed new initiatives to promote citizenship and widen access to the naturalization process for limited English proficient immigrants and immigrants who face financial hardships. Such local implementation work is crucial in realizing the benefits of the few federal policies designed with immigrants in mind.

\section{Challenges and Lessons Learned}

13 The experiences of existing state and city immigrant affairs offices highlight several challenges in addressing immigrant integration. Key is the lack of resources to get things done. Most offices have limited staff and small budgets to develop new 
integration initiatives, especially as state and municipal budgets remain under stress. Their struggle to survive and the need to justify their existence especially in places where there is opposition to immigration can detract from offices' ability to move the needle on immigrant integration. Also, state and city immigrant affairs offices are important government initiatives to promote immigrant advancement. Yet in a federal system like the United States, the federal government needs to take an active role as well. Without federal immigration reform and the implementation of a national integration program, the impact of state and city immigrant affairs offices will be limited.

14 The experiences of existing state and city immigrant affairs offices also point to successful integration practices. First, strong gubernatorial and mayoral support and leadership are critical in creating immigrant affairs offices, but their long-term viability requires institutionalization and proper staffing and funding beyond the tenure of their initial government champions. Second, to be successful, state and city immigrant affairs offices have to build broad public support and work with unexpected allies, including law enforcement officials, business and labor leaders, and leaders of organizations representing African Americans, to bring home the message that promoting immigrant integration is everyone's business. Third, it is important for state and city immigrant affairs offices to secure technical assistance from organizations like Welcoming America. No one office can go at it alone, and especially newer offices and initiatives can draw support and emulate best practices from more established offices in such networks. Fourth, state and city immigrant affairs offices need to track and evaluate their success from the beginning, which will help them to secure funding and assist them in institutionalizing the office. Finally, state and city immigrant affairs offices need to adopt a holistic approach to integration by focusing on facilitating immigrants' access to city and community resources, promoting immigrant civic engagement, and passing and implementing immigrant integration policies.

\section{NOTES}

1. Announced by President Obama in June 2012, the Deferred Action for Childhood Arrivals (DACA) program offers qualified young undocumented immigrants a two-year (renewable) stay of deportation and the ability to apply for a legal work permit. 


\section{AUTEUR}

\section{ELS DE GRAAUW}

Els de Graauw is Assistant Professor of Political Science at Baruch College, the City University of New York. She earned her Ph.D. from the Department of Political Science at the University of California, Berkeley. Her research centers on the nexus of immigration and immigrant integration, civil society organizations, (sub)urban politics, and public policy. 